\title{
The isolation, analytical characterization by HPLC-UV and NMR spectroscopy, cytotoxic and antioxidant activities of baeomycesic acid from Thamnolia vermicularis var. subuliformis
}

\author{
Nedeljko T. Manojlović ${ }^{1}$, Perica J. Vasiljević ${ }^{2}$, Dragan Nikolić ${ }^{3}$, Gordana Bogdanović-Dušanović ${ }^{3}$, \\ Zoran S. Marković ${ }^{4}$, Stevo Najman ${ }^{5}$ \\ ${ }^{1}$ Department of Pharmacy, Medical Faculty, University of Kragujevac, Kragujevac, Serbia \\ ${ }^{2}$ Department of Biology, Faculty of Science, University of Niš, Niš, Serbia \\ ${ }^{3}$ College of Applied Professional Studies, Vranje, Serbia \\ ${ }^{4}$ Department of Biochemical and Medical Sciences, State University of Novi Pazar, Novi Pazar, Serbia \\ ${ }^{5}$ Institute of Biology and Human Genetics, Faculty of Medicine, University of Niš, Niš, Serbia
}

\begin{abstract}
The aim of this work was the analytical characterization of the $\beta$-orcinol depside, baeomycesic acid in lichens extracts. The extract of Thamnolia vermicularis var. subuliformis was analyzed by two different methods, namely HPLC-UV and ${ }^{1} \mathrm{H}-\mathrm{NMR}$ analysis. The results showed that baeomycesic acid was the most abundant depside in the lichens. These results could be of use for rapid identification of this metabolite in other lichen species. Besides baeomycesic acid, three depsides and one monocyclic phenolic compound were isolated from the lichen extract on the chromatographic column. The structure of baeomycesic acid was confirmed by HPLC-UV and spectroscopic methods. In addition, antioxidant and cytotoxic activities of baeomycesic acid were determined. The result of the testing showed that baeomycesic acid exhibited a moderate radical scavenging activity $\left(I C_{50}=\right.$ $=602.10 \pm 0.54 \mu \mathrm{g} / \mathrm{mL}$ ) and good cytotoxic activity. This is the first report of detailed analytical characterization and isolation, as well as antioxidant and cytotoxic activities of baeomycesic acid from Thamnolia vermicularis. These results may be helpful in future industrial production of herbal medicines that include this important natural product.
\end{abstract}

Keywords: baeomycesic acid; NMR; HPLC; antioxidant activity; cytotoxic activity; HeLa cells.

SCIENTIFIC PAPER

UDC 615.322:543.42:547

Hem. Ind. 65 (5) 591-598 (2011)

doi: 10.2298/HEMIND110414035M

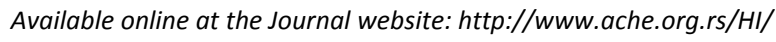

More than one thousand primary and secondary metabolites with identified structures in lichens are currently known. The most numerous classes of secondary metabolites are depsides and depsidones. Depside molecules consist of 2-4 hydroxybenzoic acid residues linked by ester groups. More than one hundred compounds are depsidones that have an additional ether bond between aromatic rings. Two tridepsides (2,4-di-O-methylgyrophoric acid and 2,4,5-tri-O-methylhiascic acid) have been isolated from Parmelia damaziana Zahlbr. [1]. Lasallic acid, a tridepside was extracted from Lasallia asiae-orientalis Whittaker \& Margulis (Umbilicariaceae) [2]. Butyrolactone acid, (-)-isomuronic acid and gyrophoric acid have been isolated from Punctelia microsticta (Mull. Arg.) Krog (Parmeliaceae) [3]. Dasypogalactone, a lactone, was isolated from Usnea dasygopa Rohl that grows in Indonesia [4]. Anthraquinone, a draculone, was isolated from the cor-

Correspondence: N. T. Manojlović, Department of Pharmacy, Medical Faculty, University of Kragujevac, Svetozara Markovića 69, 34000 Kragujevac, Serbia.

E-mail: ntm@kg.ac.rs

Paper received: 14 April, 2011

Paper accepted: 19 May, 2011 ticolous tropical lichen Melanotheca cruenta (Mont.) Miill. (Trypetheliaceae) together with anthraquinone pigment haematommone [5]. Beta-orcinol metabolites viz hypotrachynic acid, deoxystictic acid, cryptostictinolide and 8'-methylconstictic acid were isolated from lichen Hypotrachyna revoluta (Flörke) Hale. (Parmeliaceae) [6]. Lichen metabolites exert a wide variety of biological actions including antibiotic, antimycobacterial, antiviral, anti-inflammatory, analgesic, antipyretic, antiproliferative and cytotoxic effects. Even though these manifold activities of lichen metabolites have now been recognized, their therapeutic potential has not yet been fully explored and thus remains pharmaceutically unexploited [7]. A wide range of secondary compounds produced by lichens is used in pharmaceutical purposes because they have a broad spectrum of biological activities [8].

Baeomycesic acid was previously isolated from Thamnolia vermicularis and was reported to demonstrate an inhibitory effect on platelet-type 12(S)-lipoxygenase (5-lipoxygenase) in vitro using a cell-based in vitro system in human platelets [9].

The aim of this work is to identify and quantify phenolic acids composition of Umbilicaria cylindrica lichen by HPLC-UV and to evaluate the antioxidant capacity of 
methanol and chloroform extracts from the lichen using different methods including: DPPH and hydroxyl radical scavenging and metal chelating activity, as well as to screen their antimicrobial activity. Furthermore, analytical characterization of the $\beta$-orcinol depside, baeomycesic acid in the extract of Thamnolia vermicularis var. subuliformis by HPLC-UV and ${ }^{1} \mathrm{H}-\mathrm{NMR}$ analysis, isolation and determination of antioxidant and cytotoxic activities of this compound were also investigated.

\section{MATERIAL AND METHODS}

\section{Lichen material}

The lichen material was collected from the Balkan

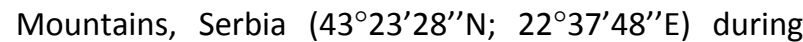
July, 2010. A voucher specimen (HMN 5490) was deposited at the Herbarium Moesiacum at the Department of Biology and Ecology, Faculty of Sciences and Mathematics, University of Niš, Serbia.

\section{Preparation of the lichen extract}

The lichen material was air-dried at room temperature $\left(26{ }^{\circ} \mathrm{C}\right)$ for one week, after which it was ground to uniform powder. The chloroform extract was prepared by soaking $500 \mathrm{~g}$ dry powdered lichen material in $2 \mathrm{~L}$ of chloroform (with stirring) at room temperature for $48 \mathrm{~h}$. The extract was then filtered through a Whatman no. $42(125 \mathrm{~mm})$ filter paper and concentrated using a rotary evaporator. The percentage yield of the extract was $6.3 \% \mathrm{w} / \mathrm{w}$ (31.5 g).

\section{High-performance liquid chromatography analysis and NMR spectroscopy}

HPLC analysis was carried out on an Agilent 1200 Series HPLC instrument with a C18 column (C18; $25 \mathrm{~cm} \times 4.6 \mathrm{~mm}, 10 \mathrm{~m}$ ) and a UV spectrophotometric detector with methanol-water-phosphoric acid (80:20:0.9 v/v/v) solvent. Methanol was of HPLC grade and was purchased from Merck (Darmstadt, Germany). Phosphoric acid was analytical-grade reagent. Deionized water used throughout the experiments was generated by a Milli-Q academic water purification system (Milford, MA, USA). The flow rate was $1.0 \mathrm{~mL} / \mathrm{min}$. The baeomycesic acid was identified by comparison of its retention time and absorption spectrum (200-600 nm) and also compared with literature data [16]. The standard compounds used in this investigation were isolated and reported from the lichen Thamnolia vermincularis var. subuliformis [20]. ${ }^{1} \mathrm{H}-\mathrm{NMR}$ spectra were recorded on Varian Unity 500 spectrometers in $\mathrm{CDCl}_{3}$. The data is reported as chemical shifts in ppm $(\delta)$.

\section{Isolation of baeomycesic acid}

The chloroform extract was dissolved with methanol and then filtered. Amount of $1 \mathrm{~g}$ of solid residue from the filter paper was chromatographed on a silica gel column (0.149-0.074 mm; 100-200 mesh) and eluted with petroleum ether-acetone gradient solvent (5:1, 3:1, 2:1 and 1:1) yielding baeomycesic acid (182 $\mathrm{mg}$ ). This solvent system was chosen based on the nature of depsides and polarity of their functional groups and confirmed by good separation of spots in TLC chromatogram. This depside was further purified by cochromatography and used for structural identifycation antioxidant and cytotoxic studies. The residue rechromatographed on the silica gel column with petroleum ether-acetone gradient solvent $(5: 1,3: 1,2: 1$ and $1: 1)$ and methanol to yield squamatic acid, barbatic acid, lecanoric acid and 6-tricosyl-2,4-dimethoxy-phenol (thamnolin). Spectral data for baeomycesic acid: HRFAB (-), MS, $m / z$ : 373.0976, calculated for $\mathrm{C}_{19} \mathrm{H}_{18} \mathrm{O}_{8}$ 373.0923. UV $\lambda_{\max }(\mathrm{nm}): 212,253,284,317 .{ }^{1} \mathrm{H}-\mathrm{NMR}$ (400 MHz, $\left.\mathrm{CDCl}_{3}, \delta / \mathrm{ppm}\right): 12,71(1 \mathrm{H}, \mathrm{s}, \mathrm{COOH}), 11.44$ $(1 \mathrm{H}, \mathrm{s}, \mathrm{OH}) 10.29(1 \mathrm{H}, \mathrm{s}, \mathrm{CHO}), 6.72\left(1 \mathrm{H}, \mathrm{s}, \mathrm{H}-1^{\prime}\right), 6.63$ $(1 \mathrm{H}, \mathrm{s}, \mathrm{H}-5), 3.76(3 \mathrm{H}, \mathrm{s}, \mathrm{OMe}), 2.35\left(3 \mathrm{H}, \mathrm{s}, \mathrm{C}_{2}-\mathrm{CH}_{3}\right)$, $2.38\left(3 \mathrm{H}, s, \mathrm{C}_{6}-\mathrm{CH}_{3}\right), 2.07\left(3 \mathrm{H}, \mathrm{s}, \mathrm{C}_{5},-\mathrm{CH}_{3}\right)$.

\section{Antioxidant activity}

\section{Free radical scavenging activity determination}

DPPH radical. 2,2-Diphenyl-1-picrylhydrazyl (DPPH) was obtained from Fluka (Buchs, Switzerland). $3.0 \mathrm{mg}$ DPPH was dissolved in $25 \mathrm{~mL}$ methanol $(0.3 \mathrm{mmol} / \mathrm{L})$. This stock solution was daily prepared, used for the measurements, and kept in the dark at ambient temperature when not used. Different concentrations of extracts (in the range 10 to $1000 \mu \mathrm{g} / \mathrm{mL}$ in methanol) were added at an equal volume $(2.0 \mathrm{~mL})$ to a methanol solution of DPPH $(0.3 \mathrm{mM}, 1 \mathrm{~mL})$. After $30 \mathrm{~min}$ at room temperature, the $A_{\mathrm{b}}$ values were measured at $517 \mathrm{~nm}$ on a double beam UV-Vis model Lambda 35 spectrophotometer (Perkin Elmer, USA) and converted into the percentage antioxidant activity using the following equation:

Activity $(\%)=\left(1-A_{b}\right.$ of sample -

$A_{\mathrm{b}}$ of blank) $/ A_{\mathrm{b}}$ of control $\times 100$

Methanol $(1.0 \mathrm{~mL})$ plus plant extract solution $(2.0$ $\mathrm{mL}$ ) was used as a blank, while DPPH solution plus methanol was used as a control. During the $30 \mathrm{~min}$ period, the reference and measuring cuvette were kept in the dark at ambient temperature. All measurements were performed in triplicate. The average and standard deviation values were presented. The $I C_{50}$ values were calculated by sigmoid non-linear regression, where the abscissa was the logarithm of concentration of tested plant extracts, and the ordinate was the average percent of scavenging capacity from three replicates (software Prizm 5.00). $I C_{50}$ values denote the concentration of sample required to scavenge $50 \%$ of DPPH radical. This parameter was introduced by Brand-Williams et al. $[10,11]$, and has been used subsequently by several 
groups of researchers for presenting their results [12-15].

\section{Cytotoxic activity}

Cell culture. The cytotoxic activity of the baeomycesic acid was tested in human epithelial carcinoma cell line - HeLa S3 (American Type Culture Collection; ATCC, Rockville, MD, USA) cell line by using the 3-(4,5-imethylthiazol-2-yl)-2,5-diphenyltetrazolium bromide (MTT) method. HeLa cells were cultured in Dulbecco's modified eagle medium (DMEM, PAA Laboratories) containing $10 \%$ fetal bovine serum (Gibco), penicillin G/streptomycin at $100 \mu \mathrm{g} / \mathrm{mL}$ and $2 \mathrm{mM} \mathrm{L-glutamine} \mathrm{(Sigma).}$ Incubation was performed at $37{ }^{\circ} \mathrm{C}$ in a humidified atmosphere with $5 \% \mathrm{CO}_{2}$.

\section{Cell viability assay}

Baeomycesic acid was dissolved in dimethylsulfoxide (DMSO) and serially diluted DMEM to obtain concentrations $50,100,150,200 \mu \mathrm{g} / \mathrm{mL}$. The final concentration of DMSO in each sample did not exceed $0.1 \%$ $\mathrm{v} / \mathrm{v}$. HeLa cells were seeded at the density of $1 \times 10^{5}$ cell/well into 96-well plates and routinely cultured for $24 \mathrm{~h}$. Cells were washed afterwards with sterile phosphate buffer (PBS) three times and after that the supernatant was discarded and BAE was added in serial concentrations. The cells were then reincubated with baeomycesic acid for 24 and $72 \mathrm{~h}$. All experiments were repeated three times.

After 24 and $72 \mathrm{~h}$ of exposure to baeomycesic acid, MTT solution ( $20 \mu \mathrm{L}$ of $5 \mathrm{mg} / \mathrm{mL}$ ) was added to each well and incubated at $37{ }^{\circ} \mathrm{C}$ for another $4 \mathrm{~h}$ followed by the medium aspiration. The formazan crystals were dissolved in $100 \mu \mathrm{L}$ acidic isopropanol $(0.04 \mathrm{M} \mathrm{HCl}$ in absolute isopropanol). The absorbance was read by Multiscan Ascent No354 (Thermo Lab Systems) ELISA reader at a wavelength of $540 \mathrm{~nm}$. Viable cell percentage is calculated by the formula:

Viable cell $(\%)=$ (the absorbance of the treated cells the absorbance of the blank)/(the absorbance of the control - the absorbance of the blank) $\times 100$

\section{Data analysis}

The concentration of sample required to inhibit cell growth by $50 \%\left(I C_{50}\right)$ in comparison with the growth of a cell control was determined from the dose-response curves. All assays were done in triplicates. Values obtained were expressed as mean \pm standard deviation.

\section{RESULTS AND DISCUSSION}

The HPLC chromatogram of the chloroform extract of $T$. vermicularis var. subuliformis is shown in Figure 1. The $t_{R}$ value for baeomycesic acid is $7.50 \mathrm{~min}$. Besides baeomycesic acid, squamatic acid ( $\left.t_{R}=4.44 \mathrm{~min}\right)$, lecanoric acid $\left(t_{R}=11.62 \mathrm{~min}\right)$ and barbatic acid $\left(t_{R}=18.77\right.$ min) were also identified. Four detected compounds belong to the depsides. Identification of these compounds was achieved by comparison of their $t_{R}$ values with the standard substances. The UV-Vis absorbance spectral data also corresponded with those in literature [16].

In addition, ${ }^{1} \mathrm{H}-\mathrm{NMR}$ analysis of the chloroform extract of the lichen was presented. Figure 2 shows ${ }^{1} \mathrm{H}$ -NMR spectrum of the chloroform extract of the lichen Thamnolia vermicularis var. subuliformis. Peaks of protons attributed to the baeomycesic acid are marked in the spectrum by asterisk. The ${ }^{1} \mathrm{H}-\mathrm{NMR}$ analysis shows that the area of 6-9 ppm and that the area below 6 ppm could not be used for the detection of this depside. That is because other depsides could also be detected in this area and it leads to overlapping of peaks. The presented spectrum shows overlapping signals that originate from the baeomycesic acid with signals originating from the squamatic, barbatic and lecanoric acid [17].

When the baeomycesic acid is the main or one of the main metabolites in the lichen then the presence of this depside can be confirmed by recording the proton spectrum of the lichen extract on the bases of three signals (singlets) in the spectrum at higher chemical shifts of 10 ppm (10.29 ppm from $\mathrm{C}_{3}-\mathrm{CHO}, 11.44 \mathrm{ppm}$ from $\mathrm{C}_{2}-\mathrm{OH}$ and $12.70 \mathrm{ppm}$ from $\mathrm{C}_{1},-\mathrm{COOH}$ ) (Figure 2). This is a very easy method for detection of baeomycesic acid in lichen extract without separation. On the other hand, multiplets (the highest signal in the spectrum, $38 \mathrm{H}$ atoms) on the chemical shifts of 1.2-1.4 ppm (marked in the spectrum with double asterisk) originating from a large number of protons that belong to 6-tricosyl-2,4-dimethoxy-phenol (thamnolin).

Since baeomycesic acid is the dominant secondary metabolite in the extract, this depside was isolated from the chloroform extract by column chromatography on silica gel together with four other compounds. Figure 3 shows UV spectrum and the structure of baeomycesic acid. The structure of this compound has been elucidated using UV and ${ }^{1} \mathrm{H}-\mathrm{NMR}$ spectra. The UV spectrum of this depside exhibited characteristic absorption bands of the depside at $\lambda_{\max } 212,253,284$ and $317 \mathrm{~nm}$.

\section{Antioxidant activity of baeomycesic acid}

It is well known that some depsides are very good antioxidants [19]. For this reason, baeomycesic acid was screened for its antioxidant potential using free radical scavenging activity (DPPH assay). Baeomycesic acid was found to have $I C_{50}$ of $602.10 \pm 0.54 \mu \mathrm{g} / \mathrm{mL}$. This result and previous studies [13-15,19] indicate that baeomycesic acid has moderate antioxidant activity $\left(I C_{50}\right.$ for butylated hydroxytoluene-BHT is $8.67 \pm 0.25$ $\mu \mathrm{g} / \mathrm{mL}$ ). Based on previous study [19], it should be concluded that the presence of phenolic groups in the molecule plays an important role in the expressing of antioxidant activity. 

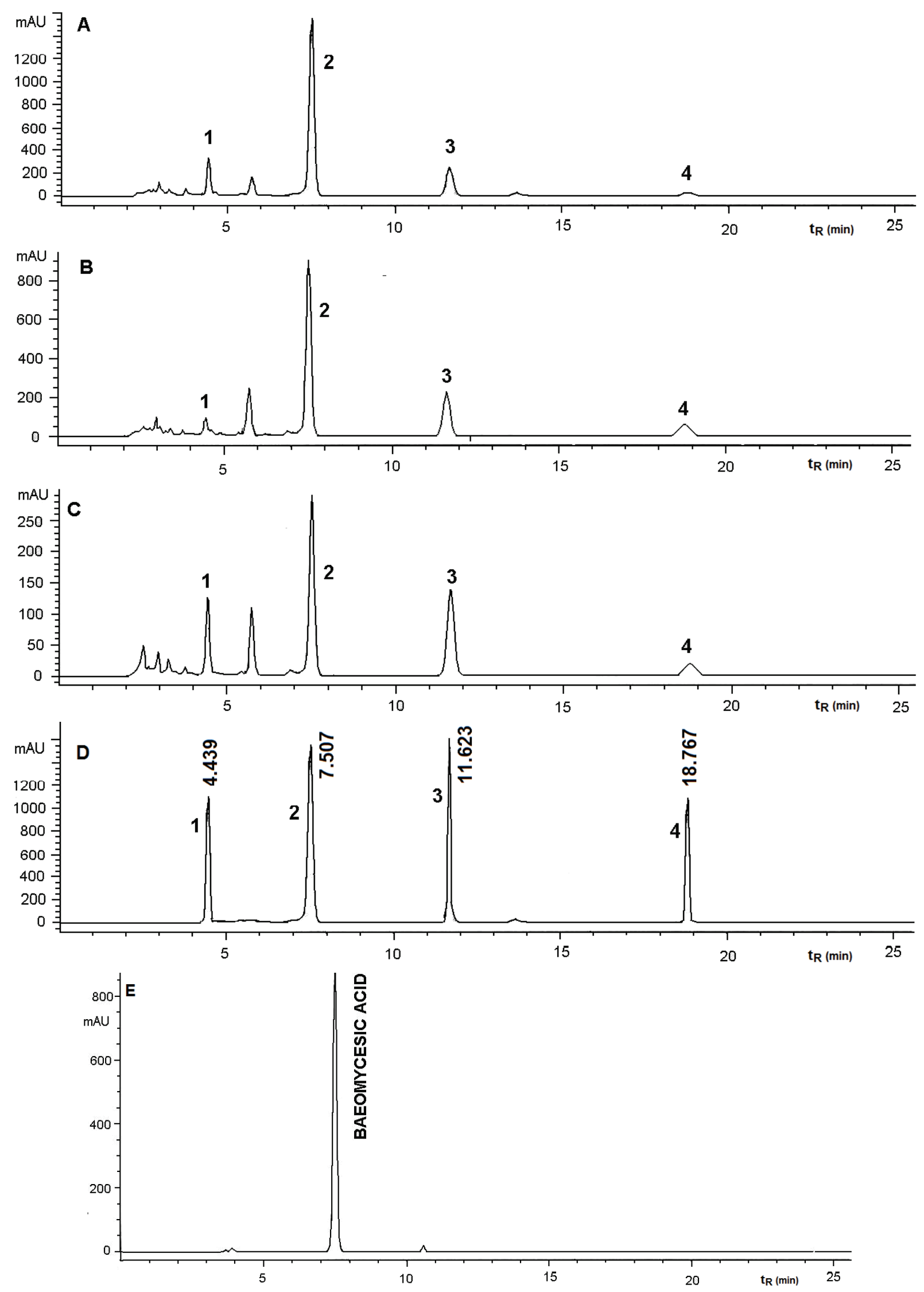

Figure 1. HPLC chromatograms of the chloroform extract of Thamnolia vermicularis recorded at A) 254; B) 280 C) $315 \mathrm{~nm}$; D) standard and E) isolated baeomycesic acid. 

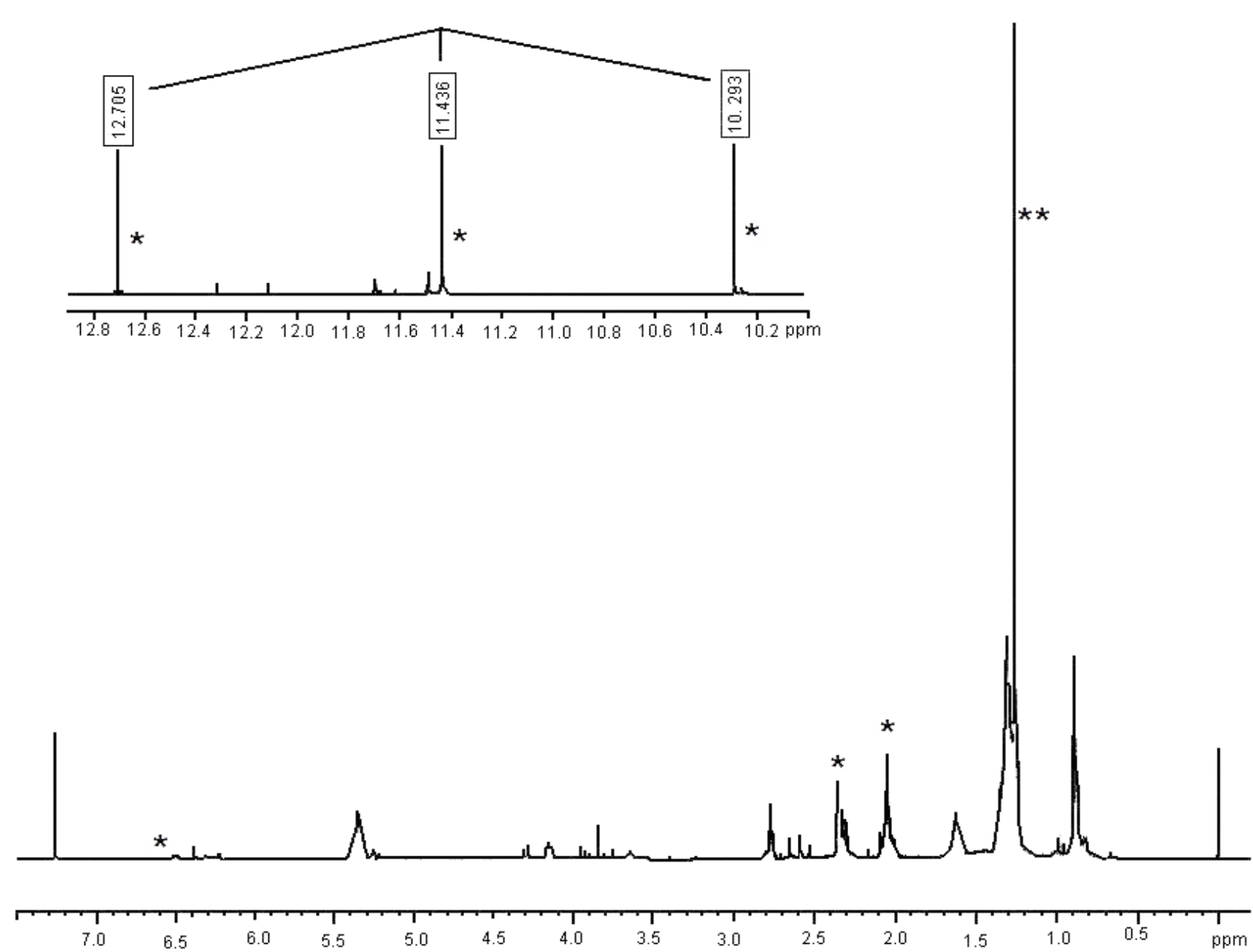

Figure 2. ${ }^{1} \mathrm{H}$-NMR Spectrum of the chloroform extract of the lichen Thamnolia vermicularis var subiliformis.

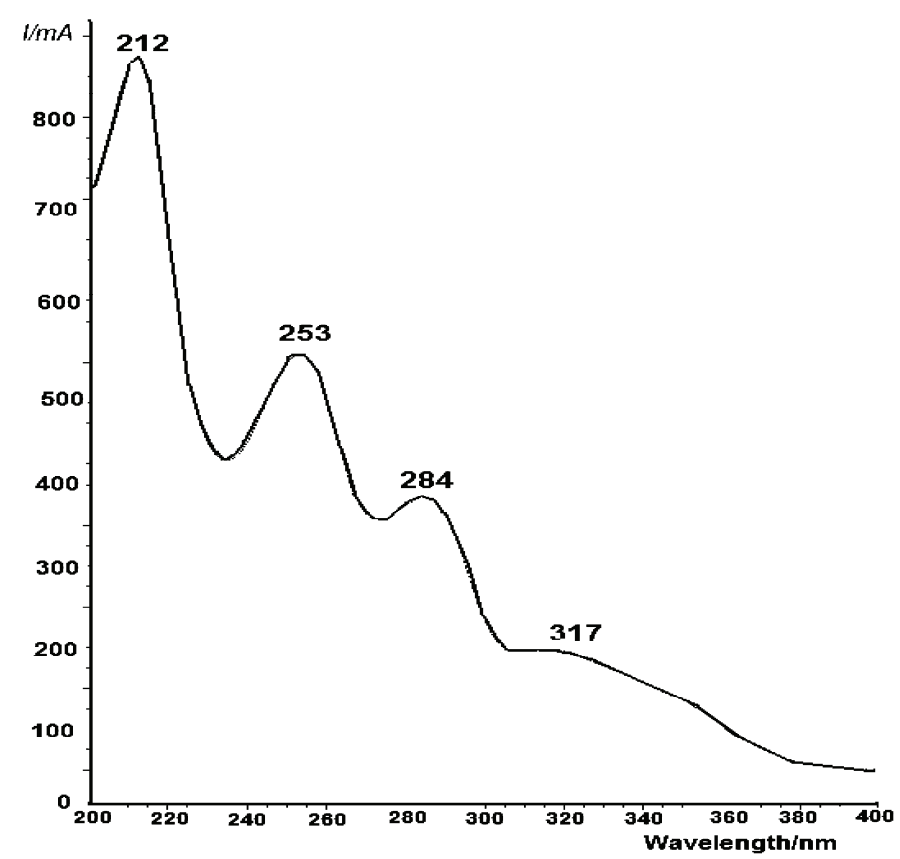<smiles>COc1cc(C)c(C(=O)Oc2cc(C)c(C(=O)O)c(O)c2C)cc1C=O</smiles>

Spectral data

UV spectrum: Absorbance maxima

$(\mathrm{nm}): 212,253,284,317$

Figure 3. The UV spectrum and the structure of the isolated baeomycesic acid recorded from the HPLC chromatogram. 


\section{Cytotoxic activity}

The results of preliminary screening for cytotoxicity of the baeomycesic acid are summarized in Figure 4, which shows that all tested concentrations of baeomycesic acid after $24 \mathrm{~h}$ of treatment of HeLa cells exhibit a cytotoxic effect. After $72 \mathrm{~h}$, exposure of cells showed inhibitory activity and $I C_{50}$ value was $135.07 \pm 28.98 \mu \mathrm{g} / \mathrm{mL}$. little has been published on the secondary metabolites present in Thamnolia sp. The results confirm the potential of HPLC-UV and NMR analysis for precise and rapid identification of this species and other baeomycesic acid-containing species and their chemotypes. The testing showed that baeomycesic acid exhibited the moderate radical scavenging activity and good cytotoxic activity.

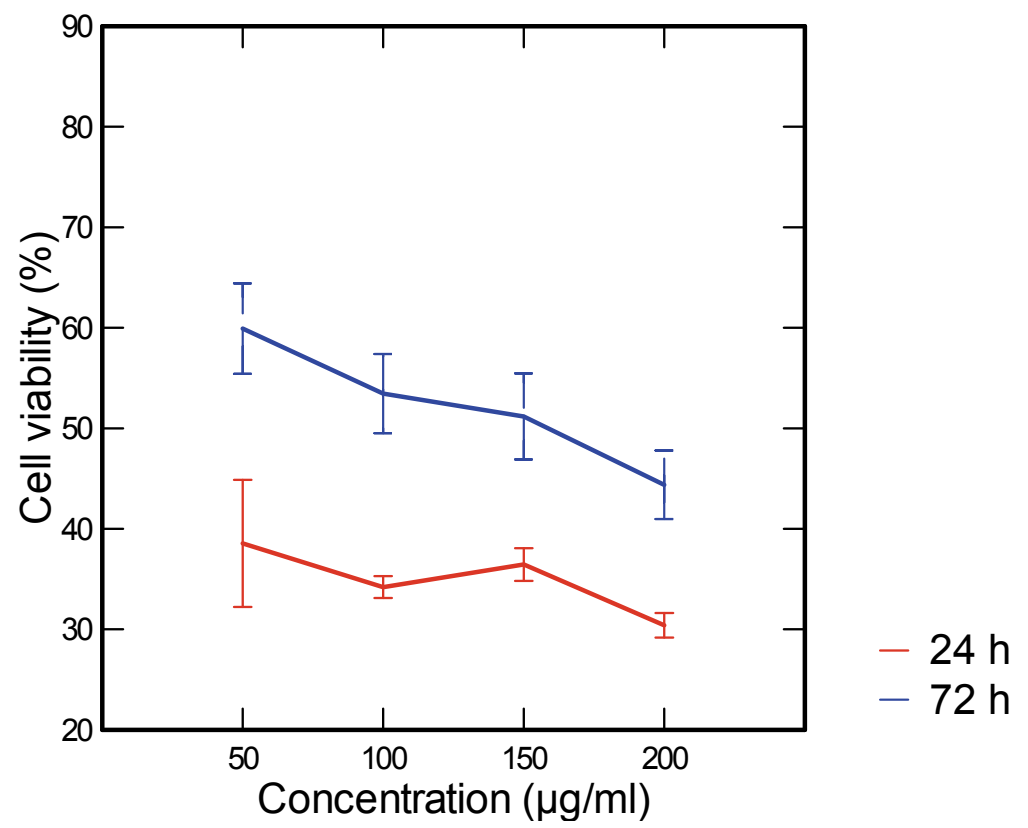

Figure 4. Effects of the BAE on the viability of HeLa S3 cell lines. Viable cells were determined using the MTT method.

The cytotoxic activity of chloroform, ethyl acetate and methanol extracts of Thamnolia vermicularis var. subuliformis was documented in the literature [20]. This preliminary study shows that baeomycesic acid has better cytotoxic activity than the tested extracts on HeLa cells. These results suggest that baeomycesic acid is the active fraction of cytotoxicity, which is consistent with previous results on the inhibitory effect on 5-lipoxygenase in vitro [9].

\section{CONCLUSION}

Two different methods for the identification of baeomycesic acid in the lichen Thamnolia vermicularis var. subuliformis were presented. The HPLC-UV method gave satisfactory results but it is necessary to have a baeomycesic acid standard. The solvent system used allows good separation of peaks in the chromatograms. On the other hand, the advantage of the NMR method is in its possibility to detect baeomycesic acid in the extract without isolation and didn't need a standard. The spectrum experiment recording time is less than that of HPLC analysis. This is of chemotaxonomic importance for Thamnolia $s p$. due to the fact that very
These results may help in future industrial production of herbal medicines with this important natural product.

\section{Acknowledgements}

The authors acknowledge the financial support of the Ministry of Science and Technological Development of the Republic of Serbia (Grant No. 172015).

\section{REFERENCES}

[1] C.C. Leznoff, V.K. Jayanthi, J.A. Elix, 2,4-Di-O-methylgyrophoric acid and 2,4,5-Tri-O-methylhiascic acid. New tridepsides from Parmelia damaziana, Aust. J. Chem. 34 (1981) 1757-1761

[2] T. Narui, K. Sawada, T. Okuyama, S. Takatsuki, C.F. Culberson, W.L. Culberson, S. Shibata, Lasallic acid, a tridepside from the lichen, Lasallia asiae-orientalis, Phytochemistry 42 (1996) 839-842

[3] M.S. Maier, D.I. Gonzalez Marimon, C.A. Stortz, M.T. Adler, Revised structure for (-)-dihydropertusaric acid, $\beta$-butyrolactone acid from the lichen Punctelia microsticta, J. Nat. Prod. 62(1999) 1565-1567

[4] W.P. Suwarso, R.L. Gani, K. Krohn, M. John, Dasypogalactone, a new C3-symmetric macrolactone from the In- 
donesian lichen Usnea dasypoga Rohl, Eur. J. Org. Chem. 7 (1999) 1719-1721

[5] A. Mathey, P. Spiteller, W. Steglich, Draculone, a new anthraquinone pigment from the tropical lichen Melanotheca cruenta, Z. Naturforsch. 57 (2002) 565-567

[6] P. Papadopoulou, O. Tzakou, C. Vagias, P. Kefalas, V. Roussis, $\beta$-orcinol metabolites from the lichen Hypotrachyna revolute, Molecules (2007) 997-1005

[7] K. Müller, Pharmaceutically relevant metabolites from lichens, Appl. Microbiol. Biotechnol. 56 (2002) 9-16

[8] J. Boustie, M. Grube, Lichens - a promising source of bioactive secondary metabolites, Plant Genetic Resources 3 (2005) 273-278

[9] S. Gissurarson, S. Sigurdsson, H. Wagner, K. Ingolfsdottir, Effect of lobaric acid on cysteinyl-leukotriene formation and contractile activity of Guinea Pig Taenia coli, J. Pharmacol. Exp. Ther. 280 (1997) 770-773

[10] W. Brand-Williams, M.E. Cuvelier, C. Berset, Use of free radical method to evaluate antioxidant activity, LWT Food Sci. Technol. 28 (1995) 25-30

[11] V. Bondet W. Brand-Williams, C Berset, Kinetics and mechanism of antioxidant activity using the DPPH free radical method, LWT - Food Sci. Technol. 30 (1997) 609-615

[12] J.K. Kim, J.H. Noh, S. Lee, J.S. Choi, H. Suh, H.Y. Chung, Y.O. Song, W.C. Choi,. The first total synthesis of 2,3,6-tribromo-4,5-dihydroxybenzyl methyl ether (TDB) and its antioxidant activity, Bull. Korean Chem. Soc. 23(5) (2002) 661-662

[13] J. Lebeau, C. Furman, J.L. Bernier, P. Duriez, E. Teissier, N. Cotelle, Antioxidant properties of di-tert-butylhydro- xylated flavonoids, Free Radic. Biol. Med. 29(9) (2000) 900-912

[14] G.G. Leitão, S.G. Leitão, W. Vilegas, Quick preparative separation of natural naphthoquinones with antioxidant activity by high-speed counter-current chromatography, Z. Naturforsch. 57c (2002) 1051-1055

[15] Y. Lu, L.Y. Foo, Antioxidant and radical scavenging activities of polyphenols from apple pomace, Food Chem. 68 (2000) 81--85

[16] I. Yoshimura, T. Kurokawa, Y. Kinoshita, Y. Yamamoto, S. Huneck, Y. Yamada, Analysis of secondary metabolites from lichen by High performance liquid chromatography with a photodiode array detector, Phytochem. Anal. 5 (1994) 197-205

[17] S. Huneck, I. Yoshimura, Identification of Lichen Substances, Berlin, Springer, 1996, pp. 168-183

[18] M.E. Hidalgo, E. Fernández, W. Quilhot, E. Lissi, Antioxidant activity of depsides and depsidones, Phytochemistry 37 (1994) 1585-1587

[19] Z.S. Markovic, N.T. Manojlovic, Analytical characterization of lichexanthone in lichen: HPLC, UV spectroscopic, and DFT analysis of lichexanthone extracted from Laurera benguelensis (Mull. Arg.), Monatsh. Chem. Chem. Mon. 141 (2010) 945-952

[20] N.T. Manojlović, P. Vasiljević, M. Jusković, S. Najman, S. Janković, A. Milenković-Andjelković, HPLC analysis and cytotoxic potential of extracts from the lichen, Thamnolia vermicularis var. subuliformis, J. Med. Plants. Res. 4 (2010) 817-823. 


\section{IZVOD}

\section{IZOLOVANJE, ANALITIČKA KARAKTERIZACIJA POMOĆU HPLC-UV I NMR SPEKTROSKOPIJE, CITOTOKSIČNA I ANTIOKSIDANTNA AKTIVNOST BEOMICESIČNE KISELINE IZ Thamnolia vermicularis VAR. subuliformis}

Nedeljko T. Manojlović ${ }^{1}$, Perica J. Vasiljević ${ }^{2}$, Dragan Nikolić ${ }^{3}$, Gordana Bogdanović-Dušanović ${ }^{3}$, Zoran S. Marković ${ }^{4}$ Stevo Najman ${ }^{5}$

${ }^{1}$ Odsek za Farmaciju, Medicinski fakultet, Univerzitet u Kragujevcu, Kragujevac, Srbija

${ }^{2}$ Departman za Biologiju i ekologiju, Prirodno-matematički fakultet, Univerzitet u Nišu, Niš, Srbija

${ }^{3}$ Visoka škola primenjenih strukovnih studija, Vranje, Serbia

${ }^{4}$ Odsek za Biohemijske i medicinske nauke, Državni Univezitet u Novom Pazaru, Novi Pazar, Srbija

${ }^{5}$ Institut za biologiju i humanu genetiku, Medicinski fakultet, Univerzitet u Nišu, Niš, Srbija

(Naučni rad)

Cilj ovog rada je analitička karakterizacija $\beta$-orcinol depsida, beomicesične kiseline u ekstraktima lišajeva. Ekstrakt lišaja Thamnolia vermicularis var. subuliformis analiziran je pomoću dve metode: HPLC-UV $\mathrm{i}^{1} \mathrm{H}-\mathrm{NMR}$, pri čemu su rezultati pokazali da je beomicesična kiselina bila najzastupljeniji depsid u ekstraktu. Ovi rezultati mogu biti od velike koristi za brzu identifikaciju ovog metabolita u i drugim vrstama lišajeva. Pored beomicesične kiseline, tri depsida i jedno monociklično fenolno jedinjenje su izolovani iz ekstrakta lišaja hromatografijom na koloni. Struktura beomicesične kiseline je potvrđena primenom HPLC-UV i spektroskopskim metodama. Pored toga, određena je antioksidantna i citotoksična aktivnost beomicesične kiseline. Rezultati su pokazali da beomicesična kiselina ispoljava umerenu aktivnost radikala (RSA), $\left(/ C_{50}=602,10 \pm 0,54 \mu \mathrm{g} / \mathrm{mL}\right)$ i dobru citotoksičnu aktivnost. U ovom radu je prvi put prikazana detaljna analitička karakterizacija, izolovanje, antioksidantna i citotoksična aktivnost beomicesična kiselina iz lišaja Thamnolia vermicularis. Rezultati mogu pomoći u budućoj industrijskoj proizvodnji biljnih preparata koji sadrže ovaj važan prirodni proizvod.

Ključne reči: Beomicesična kiselina $\bullet$ NMR - HPLC • Antioksidantna aktivnost • Citotoksična aktivnost $\bullet$ HeLa Ćelije 